\title{
Lung transplantation in China: a new era in perspective
}

\author{
Jingyu Chen, Chunxiao Hu, Xiaoshan Li \\ Wuxi Lung Transplant Center, Wuxi People's Hospital Affiliated to Nanjing Medical University, Wuxi, China \\ Correspondence to: Jingyu Chen. Wuxi Lung Transplant Center, Wuxi People's Hospital Affiliated to Nanjing Medical University, Wuxi 214000, \\ China. Email: chenjy@wuxiph.com.
}

Received: 17 February 2021; Accepted: 15 October 2021; Published: 25 February 2022.

doi: $10.21037 /$ ccts-21-10

View this article at: https://dx.doi.org/10.21037/ccts-21-10

\section{The development of lung transplantation (LTX) in China}

LTx has been an established treatment for patients with end-stage lung disease. In 1949, Demikov in the Union of Soviet Socialist Republics (USSR) first performed LTx experiments in dogs (1). A year later, in 1950, Metras in France reported a successful left LTx in dogs (2). In 1963, Hardy and Webb, at the University of Mississippi, Jackson, USA, obtained permission to perform LTx on a human recipient, who survived for 18 days but died of renal failure and infection (3). Since then, there have been attempts at lung, lobar, and heart-lung transplants, but the outcomes were disappointing (4). With the refinement in surgical techniques, the introduction of cyclosporin, and careful selection of patients, in 1983 in Toronto, Cooper and colleagues performed the first successful single LTx on a patient with idiopathic pulmonary fibrosis (IPF), who survived for 7 years after the operation but eventually died of renal failure (5). In 1986, the first successful bilateral LTx was performed by the Toronto group (6). These major landmarks ushered in the modern era of clinical LTx.

In China, clinical LTx was first attempted by Dr. Xin Yuling, an assistant to Dr. Norman Bethune, who witnessed early animal LTx experiments by Demikhov during his training in the Soviet Union. In January 1979, Dr. Xin performed a single left LTx on a 31-year-old man whose lung was severely damaged by tuberculosis. The transplanted lung developed complete white-out on the $5^{\text {th }}$ postoperative day and had to be resected on day 7 (7). In November 1979, Dr. Xin made a second attempt at LTx by performing a lobar LTx on a 22-year-old woman with lung damage owing to tuberculosis. The patient developed acute rejection, and the transplanted lung also had to be resected. Eventually, the patient succumbed to pulmonary embolism on day 32 (8). This was followed by a hiatus of more than 10 years in LTx activity in China.

In 1995, the first successful case of single LTx in China was performed by Professor Chen Yuping at the Beijing Anzhen Hospital in a patient with pulmonary fibrosis, who survived for 5 years (9). Between 1995 and 1997, Prof. Fengrui Zhao from the Beijing China-Japan Friendship Hospital performed a single LTx on three patients with pulmonary fibrosis, chronic obstructive pulmonary disease (COPD) with concurrent squamous cell carcinoma, and tuberculosis. The longest survivor died on day 48. Two of the patients died due to acute rejection, while the third patient succumbed to severe infection $(10,11)$. In 1998, the first successful bilateral LTx was performed in the Anzhen Hospital on a patient with pulmonary artery hypertension, who then survived for 4 years and 3 months (12).

However, the challenges of post-transplant infection and rejection continued to hamper the development of LTx in China. To broaden the LTx experience, many thoracic surgeons underwent further training in North American centres, notably in St. Louis and Toronto. In 2002, Dr. Jingyu Chen returned to Wuxi after training in Toronto and performed single LTx on patients with emphysema (13) (Figure 1). This marked the beginning of the Wuxi Lung Transplant Centre, which was modelled on the Toronto Lung Transplant Program, with emphasis on the transplant recipient's multidisciplinary care. Over time, Wuxi has evolved into the largest LTx program in China, and since 2016, it has been performing over 100 cases of LTx per year. In 2017, Dr. Jingyu Chen became involved in the LTx program at the China-Japan Friendship Hospital. Since then, there has been an exponential increase in LTx activity at that hospital, with 107 cases performed in 2018. At the time of writing, the centres performing the largest number 


\section{History of Lung Transplantation in China: Milestone Cases}

\begin{tabular}{|c|c|c|c|c|c|c|c|c|}
\hline Date & Hospital & $\begin{array}{c}\text { Gender /Age } \\
\text { (years) }\end{array}$ & Indication & Type & $\begin{array}{l}\text { Operation } \\
\text { time }(\mathrm{min})\end{array}$ & $\begin{array}{l}\text { Ischemic time } \\
\text { (min) }\end{array}$ & Complications & Follow-up \\
\hline $\begin{array}{c}\text { Jan } 13^{\text {th }} \\
1979\end{array}$ & $\begin{array}{l}\text { Beijing Institute } \\
\text { of Tuberculosis }\end{array}$ & Female/31 & Tuberculosis & $\begin{array}{l}\text { Single lung } \\
\text { transplantation }\end{array}$ & 345 & 255 & Acute rejection & $\begin{array}{l}\text { Resection of graft on } \\
\text { Day } 7\end{array}$ \\
\hline $\begin{array}{l}\text { Nov } 17^{\text {th }} \\
1979\end{array}$ & $\begin{array}{l}\text { Beijing Institute } \\
\text { of Tuberculosis }\end{array}$ & Female/22 & Tuberculosis & $\begin{array}{c}\text { Lobar } \\
\text { transplantation }\end{array}$ & - & 107 & Acute rejection & $\begin{array}{c}\text { Died of PE on Day } \\
32\end{array}$ \\
\hline $\begin{array}{c}\text { Feb 23 }^{\text {rd }} \\
1995\end{array}$ & $\begin{array}{c}\text { Beijing Anzhen } \\
\text { Hospital }\end{array}$ & Male/48 & $\begin{array}{l}\text { Pulmonary } \\
\text { fibrosis }\end{array}$ & $\begin{array}{l}\text { Single lung } \\
\text { transplantation }\end{array}$ & - & - & Acute rejection & $\begin{array}{l}\text { Survived in follow-up } \\
\text { to } 5 \text { years }\end{array}$ \\
\hline \multirow[t]{3}{*}{ 1995-1997 } & \multirow{3}{*}{$\begin{array}{l}\text { Beijing } \\
\text { China-Japan } \\
\text { Friendship } \\
\text { Hospital }\end{array}$} & Male/48 & $\begin{array}{l}\text { Pulmonary } \\
\text { fibrosis }\end{array}$ & \multirow{3}{*}{$\begin{array}{l}\text { Single lung } \\
\text { transplantation }\end{array}$} & - & - & Acute rejection & $\begin{array}{l}\text { Died on infection on } \\
\text { Day } 9\end{array}$ \\
\hline & & Male/56 & COPD, SCC & & - & - & Acute rejection & $\begin{array}{c}\text { Died on infection on } \\
\text { Day } 48\end{array}$ \\
\hline & & Male/52 & Tuberculosis & & - & - & $\begin{array}{l}\text { Hyperacute } \\
\text { rejection }\end{array}$ & $\begin{array}{c}\text { Died on infection on } \\
\text { Day } 43\end{array}$ \\
\hline $\begin{array}{c}\text { Jan } 20^{\text {th }} \\
1998\end{array}$ & $\begin{array}{c}\text { Beijing Anzhen } \\
\text { Hospital }\end{array}$ & Male/30 & PAH & $\begin{array}{l}\text { Bilateral lung } \\
\text { transplantation }\end{array}$ & 540 & $\begin{array}{l}\text { Right } 245 \\
\text { Left } 415\end{array}$ & $\begin{array}{l}\text { IRI, anastomosis } \\
\text { stenosis,tubercul } \\
\text { osis, } \\
\text { CMV infection }\end{array}$ & $\begin{array}{l}\text { Survived in follow-up } \\
\text { to } 2 \text { years }\end{array}$ \\
\hline $\begin{array}{l}\text { Sep } 28^{\text {th }} \\
2002\end{array}$ & $\begin{array}{c}\text { Wuxi Lung } \\
\text { Transplant center }\end{array}$ & Male/56 & $\begin{array}{c}\text { COPD, } \\
\text { emphysema }\end{array}$ & $\begin{array}{l}\text { Single lung } \\
\text { transplantation }\end{array}$ & 320 & 260 & Acute rejection & $\begin{array}{c}\text { Discharged at } \text { Day } \\
47\end{array}$ \\
\hline
\end{tabular}

Figure 1 Milestone events in the history of lung transplantation in China. Reproduced with permission (14). PE, pulmonary embolism; COPD, chronic obstructive pulmonary disease; SCC, squamous cell carcinoma; PAH, pulmonary artery hypertension; IRI, ischemiareperfusion injury; CMV, cytomegalovirus.

of LTx in China are the Wuxi People's Hospital, ChinaJapan Friendship Hospital, the First Affiliate Hospital of Guangzhou Medical University, and the Shanghai Pulmonary Hospital.

\section{Legal developments in China regarding organ procurement and utilization}

In 2003, the initial official criterion for brain death was established by the Chinese Ministry of Health, which has provided the legal foundation for the development of an organ donation program. In 2007, the Regulations on Human Organ Transplantation became the first organ transplantation law in China to be promulgated by the State Council. This established the legal basis for the development of qualified transplant centres and prohibited the illegal use of organs (15).

Amendment (VIII) to the Criminal Law of the People's Republic of China was issued by the Supreme People's Court in 2011, specifying the regulation for criminal organ trafficking. Interim Provisions on Human Organ Procurement and Allocation were implemented by the National Health and Family Planning Commission
(NHFPC) in 2013.

In 2010, the policy of donation-after-cardiac-death was initiated, and the Law of the People's Republic of China on the Red Cross Society was issued in 2017. As a result of these two laws, more than 30 regulatory documents were issued for the supervision of the process of organ donation and transplantation, especially on the prohibition of transplant tourism and regulation of living donor organ transplantation (16).

On 1 January, 2015, China officially announced that voluntarily donated organs would be the sole legal source of transplantable organs. This has had a profound impact on the medical profession and the general public at large. By 2019, there were more than a million registered organ donors, according to the China Organ Donation Administrative Centre. The transplant organs can only be from volunteer donation and where the next of kin has provided written informed consents with free will.

Historically donation after cardiac death has been the main source of donor organs in China. However with increasing acceptance of the concept of brain death by the general public and health care professionals, donation after brain death has increased in proportion and currently 


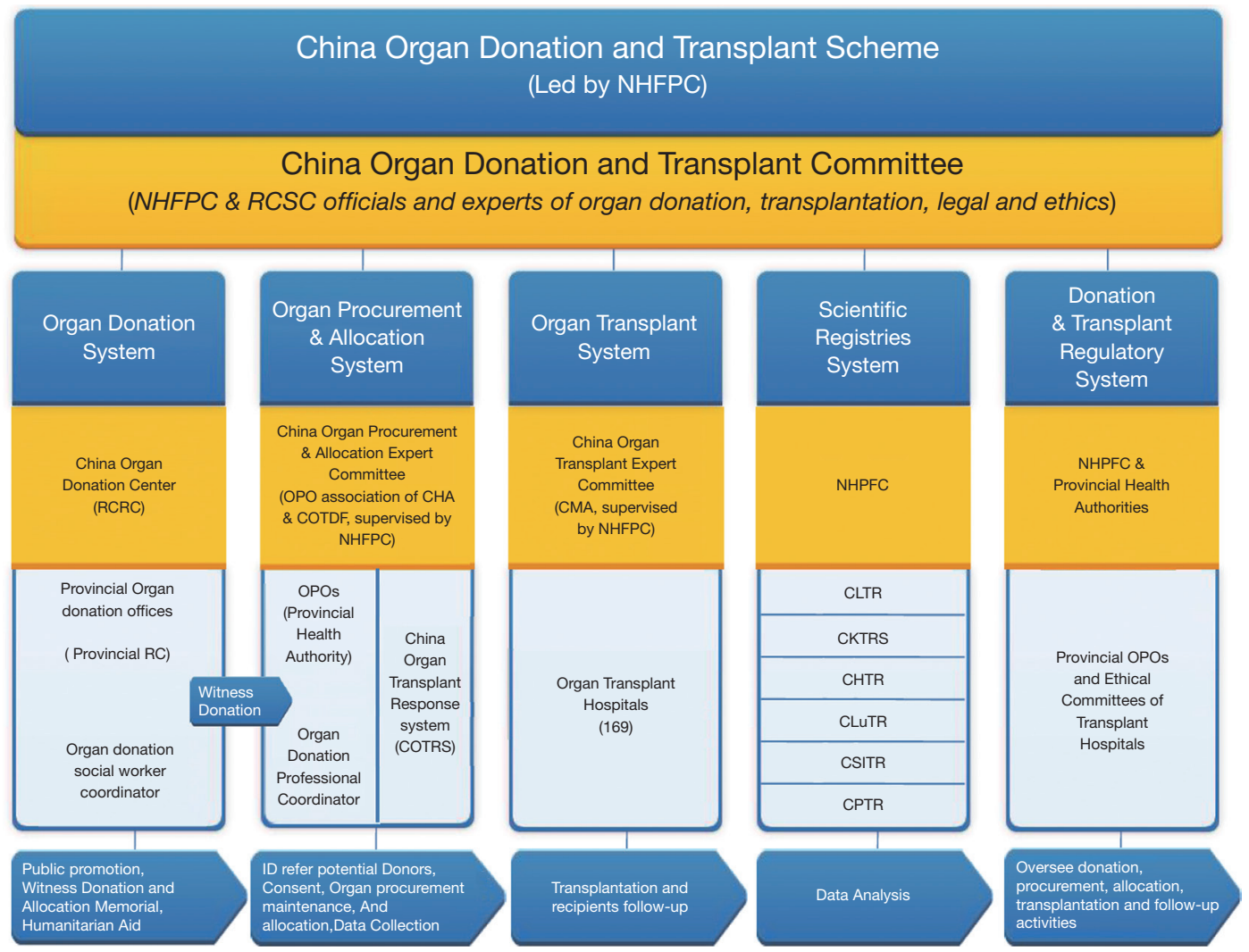

Figure 2 A new era begins with the introduction of the systems for organ donation and allocation supervised by provincial and nationallevel of health authorities. The China Organ Donation and Transplantation Committee sits at the top-level, under which there are five branches, consisting of: (I) organ donation system, (II) organ procurement and allocation system, (III) organ transplant system, (IV) scientific registration system, and (V) donation and transplant regulatory system. The China Organ Transplant Response System (COTRS) is the mandatory official organ allocation system. Reproduced with permission (14). NHFPC, the National Health and Family Planning Commission; RCSC, the Red Cross Society of China; OPO, organ procurement organization.

approaches $80 \%$ of donor organs.

\section{'Green channel' for long-distance organ transportation}

The NHFPC, the Ministry of Public Security, the Ministry of Transport, the Civil Aviation Administration of China, the China Railway Corporation, and the Red Cross Society of China (RCSC) jointly worked together to develop the Green Channel of human organ transportation. This provided a fast-tracked security check of organs, and staff involved in organ transportation and logistical support to connect high-speed trains, commercial flights, and highways seamlessly. On 6 May, 2016, the Code of Organ Transportation was enacted with a 24 -hour oncall liaison system for dispatch. Different combinations of transportation routes can be chosen to achieve the shortest transportation time, and therefore the shortest ischaemic time, for the organ in question (14).

\section{Infrastructure for organ donation and transplantation in China}

In China, organ donation and transplantation systems are supervised by the NHFPC, and this body has been integrated into a new agency called the National Health Commission in 2018. The China Organ Donation and Transplant Committee, which consists of NHFPC and RCSC officials and experts in organ donation, transplant, legal, and ethics, is at the topmost level of this structure. There are five branches under the China Organ Donation and Transplant Committee, consisting of the following: 


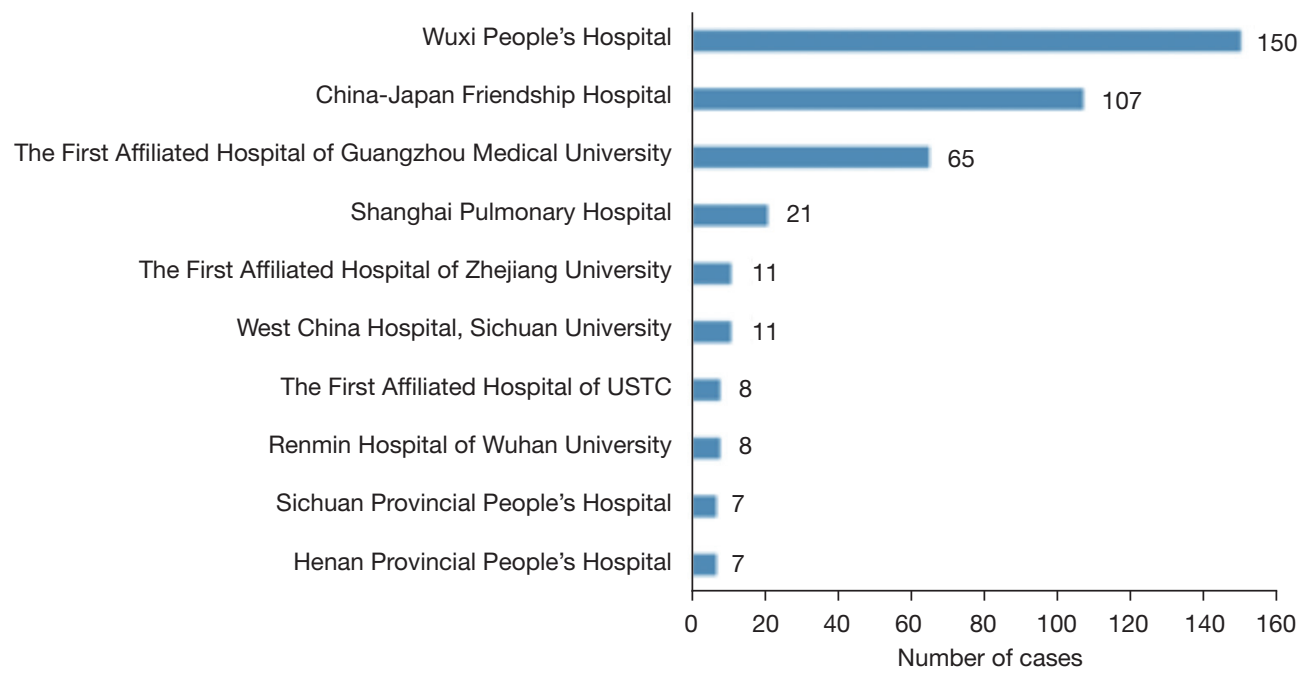

Figure 3 The top 10 medical institutions by the number of lung transplantation cases in 2018 in China. USTC, University of Science and Technology.

(I) organ donation system, (II) organ procurement and allocation system, (III) organ transplant system, (IV) scientific registration system, and $(\mathrm{V})$ donation and transplant regulatory system (Figure 2).

All organ allocations in China have to take place through the official organ allocation system, called the China Organ Transplant Response System, which performs automated patient-oriented organ matching, based on scientific organ allocation policies. Internationally recognized principles and experiences were referred to for determining the priority of allocation. The priority principles that were adopted include: region, disease severity, blood type matching, tissue matching, rare opportunities, immediate family of the organ donors (17). In 2010, the Wuxi Lung Transplant Center was given the supervisory role of the national LTx data, with the establishment of the Chinese Lung Transplantation Registry and Data Management Centre. In 2015, the China Lung Transplantation Registry (CLuTR) was brought into service. The CLuTR is a scientific registry system of LTx data in China that collects the data of donors and recipients in a comprehensive and timely manner.

By the end of 2019, the CLuTR has collected data from over 1,900 lung transplants performed in the 43 qualified LTx centres nationwide (excluding Hong Kong, Macao, and Taiwan). According to the provisions of the National Health Commission, all LTx centres in China should submit data to the CLuTR. Since its inception, 27 LTx centres have reported their data to the registry.

By the end of 2019, 43 medical institutions in China have been authorised to perform LTx. These were located across 21 provinces, with most of these centers situated in the eastern and northern parts of China. From 1 January 2015 to 31 December 2019, a total of 1,513 cases of LTx were reported to the CLuTR, including 118 cases in 2015, 204 cases in 2016, 299 cases in 2017, 403 cases in 2018, and 489 cases in 2019, showing a year-on-year increase in case volume. In 2018, LTx was performed in 23 approved centres, with the Wuxi People's Hospital (30.5\%), ChinaJapan Friendship Hospital (20.0\%), and the First Affiliated Hospital of Guangzhou Medical University (16.1\%) performing the majority of these operations (Figure 3).

\section{Conclusions}

Clinical lung transplant started in China in the 1970s, however it was in the beginning of the $21^{\text {st }}$ century when significant number of cases were being performed. The upward trend of lung transplant operations performed every year is very promising for the field. The majority of LTx operations in China have been concentrated in a handful of centers, where some of them performed over 100 LTx per year. The establishment of the legal framework on organ donation in China ensures healthy development of the field of solid organ transplantation. While many challenges still exist, nevertheless the establishment of the CLuTR promises not only appropriate matching of donor and recipients, but also a wealth of data which will further allow practitioners in China and beyond to learn from the 
Chinese lung transplant experience.

\section{Acknowledgments}

Funding: None.

\section{Footnote}

Provenance and Peer Review: This article was commissioned by the editorial office, Current Challenges in Thoracic Surgery for the series "Highlights of the First International Symposium on Lung transplantation, Wuxi, China, 2019". The article has undergone external peer review.

Conflicts of Interest: All authors have completed the ICMJE uniform disclosure form (available at https://ccts.amegroups. com/article/view/10.21037/ccts-21-10/coif). The series "Highlights of the First International Symposium on Lung transplantation, Wuxi, China, 2019" was commissioned by the editorial office without any funding or sponsorship. JC served as the unpaid Guest Editor of the series. The authors have no other conflicts of interest to declare.

Ethical Statement: The authors are accountable for all aspects of the work in ensuring that questions related to the accuracy or integrity of any part of the work are appropriately investigated and resolved.

Open Access Statement: This is an Open Access article distributed in accordance with the Creative Commons Attribution-NonCommercial-NoDerivs 4.0 International License (CC BY-NC-ND 4.0), which permits the noncommercial replication and distribution of the article with the strict proviso that no changes or edits are made and the original work is properly cited (including links to both the formal publication through the relevant DOI and the license). See: https://creativecommons.org/licenses/by-nc-nd/4.0/.

\section{References}

1. Becerra E, Kaplan J, Cooper DKC. Experimental background and early clinical experience. In: The transplantation and replacement of thoracic organs. Cooper DKC, Novitzky D. editors. Dordrecht Kluwer Academic Publishers: Boston/London, 1990;Cap33:261-72.

2. Metras H. Note preliminaire sur greffe totale du poumon chez le chien. Comp (Renal Acad Sci 1950;231:1176-7.

3. Hardy JD, Eraslan S, Webb WR. Transplantation of the lung. Ann Surg 1964;160:440-8.

4. Cooper JD. Herbert Sloan lecture. Lung transplantation. Ann Thorac Surg 1989;47:28-44.

5. Toronto Lung Transplant Group. Unilateral lung transplantation for pulmonary fibrosis. N Engl J Med 1986;314:1140-5.

6. Patterson GA, Cooper JD, Dark JH, et al. Experimental and clinical double lung transplantation. J Thorac Cardiovasc Surg 1988;95:70-4.

7. Xin YL. A case of human lung transplantation (author's transl). Zhonghua Wai Ke Za Zhi 1979;17:328-32.

8. Xin YL, Cai LP, Zhao ZW, et al. The second case report of human lung transplantation. Chin J Organ Transplant 1981;2:4-6.

9. Chen $Y$, Zhang Z, Han L. Left single lung transplantation in treatment of idiopathic pulmonary fibrosis: a case report. Zhonghua Wai Ke Za Zhi 1996;34:25-8.

10. Zhao FR, Jiang YG, Ge B, et al. Lung transplantation: 1 case. Chin J Thorac Cardiovasc Surg 1998;14:237-8.

11. Zhao F, Jiang Y, Li N. Experience and lessons of lung transplantation. Zhonghua Wai Ke Za Zhi 1997;35:616-9.

12. Chen YP, Zhou QW, Hu YS, et al. Double-lung transplantation for the treatment of primary pulmonary hypertension. Chin J Thorac Cardiovasc Surg 1998;14:321-3.

13. Chen JY, Zheng MF, He YJ, et al. Single-lung transplantation for end-stage emphysema. Zhonghua Wai Ke Za Zhi 2003;41:404-6.

14. $\mathrm{Wu} \mathrm{B}, \mathrm{Hu} \mathrm{C}$, Chen $\mathrm{W}$, et al. China lung transplantation developing: past, present and future. Ann Transl Med 2020;8:41.

15. Mao W, Xia W, Chen J. Regulation of lung transplantation in China. J Heart Lung Transplant 2012;31:1147-8.

16. Huang J. The "Chinese Mode" of organ donation and transplantation. Hepatobiliary Surg Nutr 2017;6:212-4.

17. Shi BY, Liu ZJ, Yu T. Development of the organ donation and transplantation system in China. Chin Med J (Engl) 2020;133:760-5.

doi: $10.21037 /$ ccts-21-10

Cite this article as: Chen J, Hu C, Li X. Lung transplantation in China: a new era in perspective. Curr Chall Thorac Surg 2022;4:2. 